MaPan : Jurnal Matematika dan Pembelajaran

p-ISSN: 2354-6883 ; e-ISSN: 2581-172X

Volume 8, No 2, Dec 2020 (168-178)

DOI: https://doi.org/10.24252/mapan.2020v8n2a1

\title{
LEARNING DIFFICULTIES IN SOLVING CALCULUS TESTS
}

\author{
Sumardin Raupu'1), Siti Zuhaerah Thalhah'2), Lisnasari Andi Mattoliang ${ }^{3)}$ \\ 1,2Institut Agama Islam Negeri Palopo; ${ }^{3}$ Universitas Islam Negeri Alauddin Makassar \\ 1,2Jl. Agatis Balandai Kota Palopo; 3Jl. H. M. Yasin Limpo Nomor 36 Samata-Gowa \\ Email: sumardin_aldhy@iainpalopo.ac.id1), hera@iainpalopo.ac.id²), \\ lisnasari.mattoliang@uin-alauddin.ac.id3)
}

Received September 24, 2020; Revised December 21, 2020; Accepted December 25, 2020

\begin{abstract}
:
Calculus is a branch of mathematics that is applied to solve various problems in various fields of science such as engineering, physics, medicine, chemistry, economics, and various other sciences. However, most students assume that calculus is an elusive material. Therefore, it is necessary to have a study of the difficulties of students in solving calculus questions, given the very importance of this concept in taking the next course. This study is qualitative descriptive research that involved forty-two second semester students of the Mathematics Education Program of IAIN Palopo, and six of them are the interview subjects. In data collection, it used written tests and interviews. Furthermore, the data obtained are then analyzed through reduction, data presentation, and conclusions withdrawal. The findings show that the students get learning difficulties in reading by $52.38 \%$, in writing by $66.67 \%$, and in accounting by $57.14 \%$. The factors causing these difficulties, namely students are not able to identify questions, difficulties in using integral symbols, difficulties in using proper techniques and formulas, difficulties in understanding the steps to solve partial integral problems, difficulties in calculations, difficulties in solving until the final stage of the integral process.
\end{abstract}

Keywords: Academic Learning Difficulties, Calculus

\section{KESULITAN BELAJAR DALAM MENYELESAIKAN SOAL KALKULUS}

\begin{abstract}
Abstrak:
Kalkulus merupakan cabang dari ilmu matematika yang diterapkan untuk menyelesaikan berbagai problema dalam berbagai bidang ilmu seperti teknik, fisika, kedokteran, kimia, ekonomi dan berbagai ilmu lainnya. Namun demikian sebagian besar mahasiswa menganggap bahwa materi kalkulus merupakan materi yang sulit dipahami. Oleh karena itu, perlu adanya suatu kajian tentang kesulitan yang dialami mahasiswa dalam menyelesaikan soal kalkulus mengingat sangat pentingnya konsep ini dalam menempuh mata kuliah berikutnya. Jenis penelitian ini adalah penelitian deskriptif kualitatif, yang melibatkan 42 mahasiswa Semester II Program Studi Tadris Matematika IAIN Palopo, dan 6 orang diantaranya merupakan subjek wawancara. Pengumpulan data dalam penelitian ini menggunakan tes tertulis dan wawancara. Selanjutnya data yang diperoleh dianalisis melalui reduksi, penyajian data dan penarikan kesimpulan. Hasil penelitian ini menunjukkan bahwa mahasiswa yang
\end{abstract}


mengalami kesulitan belajar membaca sebesar 52,38\%, kesulitan belajar menulis sebesar $66,67 \%$ dan kesulitan belajar berhitung sebesar 57,14\%. Faktor penyebab kesulitan tersebut, yaitu mahasiswa tidak mampu mengidentifikasi soal, kesulitan dalam penggunaan simbol integral, kesulitan dalam penggunaan teknik dan rumus yang tepat, kesulitan memahami langkah penyelesaian soal integral parsial, kesulitan dalam perhitungan, kesulitan dalam menyelesaikan sampai tahap akhir proses integral.

Kata Kunci: Kesulitan Belajar Akademik, Kalkulus

How to Cite: Raupu, S., Thalhah, S. Z., \& Mattoliang, L. A. (2020). Learning Difficulties in Solving Calculus Tests. MaPan : Jurnal Matematika dan Pembelajaran, 8(2), 168-178. https://doi.org/10.24252/mapan.2020v8n2a1.

\section{INTRODUCTION}

U

niversity as the higher education institution uses 'lecturing' as the term for the teaching-learning process (Mutakin, 2013). Fatimah and Yerizon (2019) assumed that one of the majors in college that explores mathematics is a mathematics education program that focuses on becoming a math teacher. Nur argued that mathematics has an important role to develop human's thinking skills (Nur, 2013). In connection with the many things that students learn in mathematics so that students often get difficulties in learning mathematics (Sugiarti, 2016). Even the National Institute of Neurological Disorders and Stroke defined learning difficulties as deficiencies that affect the ability to understand or use written and spoken language, mathematical calculations, movement coordination, or directing attention (Runtukahu \& Kandou, 2014).

Problems in learning are the core issues of education and learning problems as the main activities in education (Rachmawati, 2017). Kereh, Sabandar, and Tjiang in Dirgantoro (2019) state that difficulties in learning mathematics can occur at any level of education. Even the learning difficulty in mathematics can be seen from students' inability to solve a problem (Amin, 2016; Wasida \& Hartono, 2018; Tyas \& Wutsqa, 2015).

At a certain level, some students can overcome their learning difficulties without getting others' help. Other students who have not yet been able to overcome their learning difficulties, really need others' help such as educators or a kind of them who has capability in mathematics. An educator must know the factors of learning difficulties that are experienced by students before 
assisting them, so that the problems that they face can be solved completely. Learning difficulties are not only experienced by low-skilled students, but also it is experienced by high-skilled students. Moreover, learning difficulties are also experienced by an average-skilled student (normal) due to some factors that hinder academic performance in accordance with expectations (Rahman, Sulkifli, \& Hasyim, 2014).

An educator cannot make any decisions in helping his or her students who have learning difficulties if they do not know what difficulties they face. The gap between the potential and students' progress can be appeared as a result of students' difficulty in understanding, using spoken and written language which caused difficulty in thinking, speaking, reading, writing, and mathematical operations (Kumalasari \& Sugiman, 2015). Among students have not the same difficulties experiences. Some of them get difficulty in reading, maybe only in writing, in counting, or even experiencing them all. Therefore, an educator needs to know the difficulties differences which are experienced by students in learning mathematics to minimize learning barriers in achieving learning goals (Yuwono, 2016).

Kirl and Galagher in Runtukahu and Kandou (2014) stated that there are four causes of learning difficulties, namely physical condition factors, environmental factors, motivational factors, attitude factors, and psychological factors. This is based on the observation that the researchers face in the field which shows the students still experience learning difficulties in mathematics, for example, the score of students' learning outcomes is still low. Moreover, researchers observed that learning difficulties at the second-semester students of the Mathematics Education Program of IAIN Palopo were caused by the lacking of mastery of prerequisite concepts from the materials taught. The interconnectedness of each concept is tightly and neatly in mathematics, so that understanding a concept will greatly support other concepts. For example, if a student cannot do the calculation, he or she will experience difficulties in multiplication, and so on.

As well as the understanding concept of Calculus Course I, it will have a great effect on the completion concepts in the course of Calculus II, because it contains applicative material in daily life as well as as a Prerequisite Course for the next course so that the students should be able to master the material contained in this course (Nuraeni, 2018). Sugiarti (2016) added that one of the mathematics subjects related to one or more other subjects means that if the 
student gets difficulty in learning one part that will affect the students' difficulty in learning other parts of mathematics.

Loc and Hoc (2014) argued that calculus has a very high intrinsic complexity that involves an infinite completion process which caused a person will experience difficulties and obstacles when they learn Calculus and will do many mistakes when they try to solve calculus. Monariska (2019) in her interview, revealed that alongside students of level II Mathematics Education Study Program Suryakancana University, most students believed that Integral Material Calculus Courses are the difficult material ones. The application of calculus in science and engineering is used to help solving complex problems that cannot be solved through basic algebraic techniques. Oktaviyanthi and Supriani (2015) assumed that most students are only able to do simple calculations. The matter becomes a challenge for teachers to find out alternative solutions in learning. Calculus is not only to attract and motivate students, but it is also to provide prospects for students in developing their skills in understanding, arguing, and solving the problem. Yaman (2019) believed that interpreting life through mathematics can begin by learning calculus.

Calculus consists of calculus I, II, and advanced level. Calculus II is one of the mandatory courses for students of mathematics education where the material requires a very thorough and diverse way of solving the given test. In the learning process in the classroom, students often get difficulty understanding Calculus II courses. For example, in integration engineering materials, many students still get difficulties determining which techniques are appropriately used for the integration issues provided due to several causative factors.

Sumargiyani and Nafi'ah (2020) in their research entitled "Analysis of Students' Difficulty in Resolving Differential Calculus Problems" data revealed that most students get difficulty in working on differential calculus exams due to various factors which caused students to get errors in answering differential calculus questions. That finding confirms that difficulty is the cause of mistakes in strategy, calculation, concept, logical decision, redraw conclusion, using symbols, and inaccuracies in answering questions. Moreover, Purbaningrum (2019) in his research found that there are three types of student difficulties in completing continuity in Calculus, namely: (1) difficulty in formulating a number line; (2) difficulty in carrying out continuity testing of functions; (3) difficulty in drawing graphs of function sketches. The causes of the problem are the mastery of the basic mathematical concepts learned in the first semester is 
not well recognized, less able to understand the meaning of the questions, and less time that can be used to explore the material being studied.

Kumalasari (2016) believed that the difficulties experienced by students in working on math problems need to be further analyzed to find out the causative factors which can overcome the students' problems who experience various mistakes in working on the test to get the maximum test results. Therefore, researchers are interested to observe the causes of learning difficulties, and this research is expected to recommend solutions in solving their learning difficulties.

\section{METHODS}

This research is a qualitative method that involved forty-two students of IAIN Palopo in the Mathematics Education Program. Six people are selected to become the interview subject that is determined through the test results that took two people from each group in high, moderate, and low level.

The grouping criteria are based on mathematical connection ability, Wardatun in Sholekah, Anggreini, and Waluyo (2017) suggested that the group of students who have an $X \geq 58.6$ are the students who have high mathematical connection skills. The group of students with a score of $25.55<X<58.6$ are the students who have moderate mathematical connection skills. The group of students who have an $X \leq 25.55$ is the students with low mathematical connection skills. The research used validated written tests, and interview guidelines to explore the types of learning difficulties that the students experience and the factors that caused students to get learning difficulties academically. Moreover, the researchers used reduction, data presentation, and conclusion withdrawal as the analysis techniques (Sugiyono, 2013).

\section{RESULTS AND DISCUSSION}

The research findings of learning difficulties in solving calculus tests can be seen in table 1 , table 2 , and table 3.

Table 1. Percentage Recapitulation of Learning Difficulty Level in Reading

\begin{tabular}{cccc}
\hline Level & Criteria & Frequency & Percentage \\
\hline $0 \% \leq \mathbf{P}<\mathbf{2 0} \%$ & Very Low & 0 & 0 \\
$20 \% \leq \mathbf{P}<\mathbf{4 0} \%$ & Low & 19 & 45.24 \\
$40 \% \leq \mathbf{P}<\mathbf{6 0} \%$ & Enough & 22 & 52.38 \\
$60 \% \leq \mathbf{P}<\mathbf{8 0} \%$ & High & 1 & 2.38 \\
$80 \% \leq \mathbf{P}<\mathbf{1 0 0} \%$ & Very High & 0 & 0 \\
\hline
\end{tabular}

172| Volume 8, No 2, December 2020 
Table 2. Percentage Recapitulation of Learning Difficulty Level in Writing

\begin{tabular}{cccc}
\hline Level & Criteria & Frequency & Percentage \\
\hline $0 \% \leq \mathbf{P}<\mathbf{2 0} \%$ & Very Low & 1 & 2.38 \\
$20 \% \leq \mathbf{P}<\mathbf{4 0} \%$ & Low & 28 & 66.67 \\
$40 \% \leq \mathbf{P}<\mathbf{6 0} \%$ & Enough & 13 & 30.95 \\
$60 \% \leq \mathbf{P}<\mathbf{8 0} \%$ & High & 0 & 0 \\
$80 \% \leq \mathbf{P}<\mathbf{1 0 0} \%$ & Very High & 0 & 0 \\
\hline
\end{tabular}

Table 3. Percentage Recapitulation of Learning Difficulty Level in Counting

\begin{tabular}{cccc}
\hline Level & Criteria & Frequency & Percentage \\
\hline $0 \% \leq \mathbf{P}<\mathbf{2 0} \%$ & Very Low & 16 & 38.10 \\
$20 \% \leq \mathbf{P}<\mathbf{4 0} \%$ & Low & 24 & 57.14 \\
$40 \% \leq \mathbf{P}<\mathbf{6 0} \%$ & Enough & 2 & 4.76 \\
$60 \% \leq \mathbf{P}<\mathbf{8 0} \%$ & High & 0 & 0 \\
$80 \% \leq \mathbf{P}<\mathbf{1 0 0} \%$ & Very High & 0 & 0 \\
\hline
\end{tabular}

Based on three tables of difficulty recapitulation levels, it can be noted that the largest percentage of students who get learning difficulties in reading is about $52.38 \%$ in 'Enough' category, writing is about $66.67 \%$ in 'low' category and counting is about $57.14 \%$ in 'low' category. Monariska (2019) strengthened this research findings about students' learning difficulties, she assumed that learning difficulties are not only in reading, writing, and counting, but the difficulty experienced by students is more about the error in understanding the test, in process skills and becoming careless in answering the questions and managing the time which caused the problem cannot be resolved properly.

Furthermore, the interview results of 6 students to find out the factors that cause the students to experience academic learning difficulties are presented in table 4 , table 5 , and table 6 below.

Table 4. Group Interview Results in Bottom/Low Level

\begin{tabular}{ccl}
\hline Subject & No. & \multicolumn{1}{c}{ Findings } \\
\hline Wildayani & 1 & $\begin{array}{l}\text { The students have not yet been able to distinguish the } \\
\text { integral questions that are solved by direct substitution } \\
\text { or using examples. }\end{array}$ \\
& 2 & $\begin{array}{l}\text { The students get difficulties in understanding the steps } \\
\text { of completing a partial integral question. }\end{array}$ \\
4 \& & $\begin{array}{l}\text { The students get difficulty in understanding the right } \\
\text { techniques for integral questions. }\end{array}$ \\
6 & $\begin{array}{l}\text { The students get difficulty in identifying what is known } \\
\text { and asked in the test. }\end{array}$ \\
\hline
\end{tabular}




\begin{tabular}{ccl}
\hline $\begin{array}{c}\text { Deni } \\
\text { Sarimin }\end{array}$ & 1 & $\begin{array}{l}\text { The students are still confused in writing identity on } \\
\text { integral. }\end{array}$ \\
& 2 & $\begin{array}{l}\text { The students get difficulty in remembering the names of } \\
\text { mathematical symbols in calculus questions. }\end{array}$ \\
$4 \&$ & $\begin{array}{l}\text { The students get difficulty in understanding the right } \\
\text { techniques for integral questions. }\end{array}$ \\
6 & $\begin{array}{l}\text { The students get difficulty in identifying what is known } \\
\text { and asked in the questions. }\end{array}$ \\
\hline
\end{tabular}

Table 5. Results of Group Interviews in Moderate Level

\begin{tabular}{|c|c|c|}
\hline Subject & No. & Findings \\
\hline \multirow[t]{4}{*}{ Dahniar } & 1 & $\begin{array}{l}\text { The students get difficulty in determining the steps which } \\
\text { integral symbols are no longer used. }\end{array}$ \\
\hline & 4 & $\begin{array}{l}\text { The students get difficulty in using the right techniques for } \\
\text { integral questions. }\end{array}$ \\
\hline & 5 & $\begin{array}{l}\text { The students get difficulty in choosing the right formula } \\
\text { for that question. }\end{array}$ \\
\hline & 6 & $\begin{array}{l}\text { The students do not know the writing that is asked in the } \\
\text { question. }\end{array}$ \\
\hline \multirow[t]{3}{*}{ Wahyuni } & 1 & $\begin{array}{l}\text { The students get difficulty in calculations, especially those } \\
\text { involving division and the degree of number. }\end{array}$ \\
\hline & $\begin{array}{c}4 \& \\
5\end{array}$ & $\begin{array}{l}\text { The students get difficulty in choosing the right formula } \\
\text { for the question. }\end{array}$ \\
\hline & 6 & $\begin{array}{l}\text { The students get difficulty in identifying what is known } \\
\text { and asked in the questions. }\end{array}$ \\
\hline
\end{tabular}

Table 6. Top Group Interview Results

\begin{tabular}{ccl}
\hline Subjek & No. & \multicolumn{1}{c}{ Findings } \\
\hline $\begin{array}{c}\text { Nurul } \\
\text { Rahma }\end{array}$ & 1 & $\begin{array}{l}\text { The students have not yet been able to distinguish the } \\
\text { integral questions that are solved by direct substitution or } \\
\text { using examples. }\end{array}$ \\
Rahma & $4 \&$ & $\begin{array}{l}\text { The students get difficulty in completing until the final } \\
\text { stage in the integral process. } \\
\text { Thi R. }\end{array}$ \\
& & $\begin{array}{l}\text { The students get difficulty in choosing the right formula } \\
\text { for the question. }\end{array}$ \\
\hline
\end{tabular}

Based on the interview results, it is found that the students get difficulty in interpreting symbols, letters, and numbers through visual and auditory perception. The results reveal that there are twenty-two students with a percentage of $52.38 \%$ who get difficulty in reading. It can be seen in the reality that students cannot read symbols, in writing identity on integral of course, they 
also get difficulty in remembering the names of mathematical symbols in calculus. Besides, students get difficulty in identifying what is known and asked questions. Other students are still confused in distinguishing the use of integral signs in calculus. The problem that students face is getting learning difficulties in remembering the names of the symbols, lacking the mentioning habituation, and using those. This is because students have not yet mastered the previous material as the requirement in mastering the next material. Ristiyani \& Bahriah (2016) argued that learning difficulties often appear as the difficulties which caused not mastering the prerequisite skills that must be mastered before mastering the next skill. Also, the main factor in learning difficulty is a lack of understanding of the questions at 'low' level (Apriandi \& Krisdiana, 2016).

Furthermore, there are twenty-eight students with a percentage of $66.67 \%$ who get learning difficulty in writing in the 'low' category. The students get difficulties in creating letters or mathematical symbols. This can be seen by students who get errors in determining the right formula in given questions. Besides, some students get difficulty in using the right techniques for the integral question, and they get difficulty in steps where integral symbols are no longer used and have not yet been able to distinguish the integral questions that are solved by direct substitution or using an example. Monariska (2019) defined that the difficulties experienced by students also lie in errors of understanding the question, in process skills (including algorithmic miscalculation, symbol writing, and using example before performing an integral calculus), as well as errors due to the careless on answering the question.

The last, the percentage of the students' learning difficulties in counting is $57.14 \%$ which is categorized as 'low' level. The students get difficulty in solving math problems and understanding the mathematics basic concepts. This is characterized by the inability of students to solve calculations through algebraic forms. Because the students still do not understand the concept of algebraic forms. Some students get difficulty completing until the final stage of the integration process. Some students get difficulty in calculations, especially in division and number of degrees.

The students get difficulty in understanding the steps of resolving partial integral questions, and they do not know the next step in finding integral results. This is caused by lacking training and still do not understand the algebraic process in the calculus process. Sumargiyani \& Nafi'ah (2020) strengthened these findings based on their research who believed that students are still confused in taking the correct calculation steps. In addition, students are not 
good at mastering derivative concepts and function limits because they are demanded to memorize formulas rather than they tried to understand it well. Usman and Hussaini (2017) also argued that students get difficulties in manipulating and problem solving processes.

\section{CONCLUSION}

Based on the findings, it can be concluded that the students' learning difficulties at the second semester of the Mathematics Education Program of IAIN Palopo get difficulties in completing the question of calculus II, such as in reading which is amounted to $52.38 \%$ in 'enough' category, difficulties in writing is about $66.67 \%$ in 'low' category and difficulties in counting is about $57.14 \%$ in 'low' category. The factors causing these difficulties, namely students are not able to identify questions, difficulties in using integral symbols, difficulties in using proper techniques and formulas, difficulties in understanding the steps to solve partial integral problems, difficulties in calculations, difficulties in solving until the final stage of the integral process. This research recommends to all lecturers that they should convey calculus material to be more varied in providing training questions and emphasizing understanding concepts in learning.

\section{REFERENCES}

Amin, A. K. (2016). Diagnostic of students' difficulties in solving mathematics problems of national examination. Journal of Research and Advances in Mathematics Education, 2(2), 81-88. Retrieved from http://journals.ums. ac.id/index.php/jramathedu.

Apriandi, D., \& Krisdiana, I. (2016). Analisis kesulitan mahasiswa dalam memahami materi integral lipat dua pada koordinat polar mata kuliah kalkulus lanjut. In Al-Jabbar: Jurnal Pendidikan Matematika, 7(2). Retrieved from http://ejournal.radenintan.ac.id/index.php/aljabar/article/view /19.

Dirgantoro, K. P. S. (2019). Analisis kesulitan mahasiswa PGSD pada mata kuliah geometri. Jurnal Nasional Pendidikan Matematika), 3(1), 13-26. https://doi.org/10.33603/jnpm.v3i1.1008.

Fatimah, S., \& Yerizon. (2019). Analysis of difficulty learning calculus subject for mathematical education students. International Journal of Scientific $\mathcal{E}$ Technology Research, 8(03). Retrieved from https://www.ijstr.org/final -print/mar2019/ Analysis-Of-Difficulty-Learning-Calculus-Subject-ForMathematical-Education-Students.pdf.

Kumalasari, A., \& Sugiman. (2015). Analisis kesulitan belajar mahasiswa pada 
mata kuliah kapita selekta matematika sekolah menengah. In Jurnal Riset Pendidikan Matematika, 2(1). Retrieved from https://journal.uny.ac.id/ index.php/jrpm/article/view/7147.

Kumalasari, E. (2016). Analisis faktor kesulitan terhadap kesalahan penyelesaian soal persamaan linear berdasarkan klasifikasi taksonomi Bloom. Jurnal Penelitian Pendidikan dan Pengajaran Matematika (JP3M), 2(2). https:// doi.org/10.37058/jp3m.v2i2.163.

Loc, N. P., \& Hoc, T. C. T. (2014). A survey of 12th grade students' errors in solving calculus problems. International Journal of Scientific $\mathcal{E}$ Technology Research, 3(6), 107-108. Retrieved from https://issuu.com/ijstr.org/docs /a-survey-of-12th-grade-students-err.

Monariska, E. (2019). Analisis kesulitan belajar mahasiswa pada materi integral. Jurnal Analisa, 5(1), 9-19. https:// doi.org/10.15575/ja.v5i1.4181.

Mutakin, T. Z. (2013). Analisis kesulitan belajar kalkulus 1 mahasiswa teknik informatika. Jurnal Formatif, 3(1), 49-60. https://dx.doi.org/10.30998/ formatif.v3i1.113.

Nur, F. (2013). Faktor-faktor penyebab berpikir pseudo dalam menyelesaikan soal-soal kekontinuan fungsi linear yang melibatkan nilai mutlak berdasarkan gaya kognitif mahasiswa. MaPan: Jurnal Matematika Dan Pembelajaran, 1(1), 70-91. Retrieved from http://journal.uin-alauddin. ac.id/index.php/Mapan/article/view/1127.

Nuraeni, R. (2018). Perbandingan kemampuan komunikasi matematis mahasiswa antara yang mendapatkan pembelajaran group investigation dengan konvensional. Mosharafa: Jurnal Pendidikan Matematika, 7(2), 219_ 228. Retrieved from http://journal.institutpendidikan.ac.id/index.php/ mosharafa.

Oktaviyanthi, R., \& Supriani, Y. (2015). Utilizing microsoft mathematics in teaching and learning calculus. Journal on Mathematics Education, 6(1), 6376. https://doi.org/10.22342/jme.6.1.1902.63-76.

Purbaningrum, K. A. (2019). Analisis Kesulitan Mahasiswa dalam Memahami Materi Kontinuitas Fungsi Mata Kuliah Kalkulus Diferensial. Math Didactic: Jurnal Pendidikan Matematika, 5(2), 199-209. https://doi.org/ 10.33654/ math.v5i2.612.

Rachmawati, T. K. (2017). An analysis of students' difficulties in solving story based problems and its alternative solutions. JRAMathEdu (Journal of Research and Advances in Mathematics Education), 1(2), 140-153. https:// doi.org/10.23917/jramathedu.v1i2.3720.

Rahman, U., Sulkifli, \& Hasyim, M. (2014). Kesulitan belajar (Kasus pada siswa MI madani Paopao Gowa). Auladuna, 1(2), 218-228. Retrieved from http:// journal.uin-alauddin.ac.id/index.php/auladuna/article/view/ 552.

Ristiyani, E., \& Bahriah, E. S. (2016). Analisis kesulitan belajar kimia siswa di 
SMAN X kota Tangerang Selatan. Jurnal Penelitian dan Pembelajaran IPA, 2(1), 18-29. http://dx.doi.org/10.30870/jppi.v2i1.431.

Rosadalima Wasida, M., \& Hartono, H. (2018). Analisis kesulitan menyelesaikan soal model ujian nasional matematika dan self-efficacy siswa SMA. Jurnal Riset Pendidikan Matematika, 5(1), 82-95. https:/ / doi.org/10.21831/jrpm. v5i1.10060.

Runtukahu, J. T., \& Kandou, S. (2014). Pembelajaran matematika dasar bagi anak berkesulitan belajar (Cet. I). Yogyakarta: Ar-Ruzz Media.

Sholekah, L. M., Anggreini, D., \& Waluyo, A. (2017). Analisis kesulitan siswa dalam menyelesaikan soal matematika ditinjau dari koneksi matematis materi limit fungsi. WACANA AKADEMIKA: Majalah Ilmiah Kependidikan, 1(2), 151-164. Retrieved from https://jurnal.ustjogja.ac.id/ index.php/wacanaakademika/article/view/1413.

Sugiarti, L. (2016). Kesulitan siswa dalam menyelesaikan soal operasi bentuk aljabar. Prosiding Seminar Nasional Etnomatnesia, 232-330. Retrieved from https://jurnal.ustjogja.ac.id/index.php/etnomatnesia/article/view/23 32.

Sugiyono. (2013). Metode penelitian kombinasi (Cet.IV). Bandung: Alfabeta.

Sumargiyani, \& Nafi'ah, B. (2020). Analisis kesulitan mahasiswa dalam menyelesaikan soal kalkulus diferensial. PRISMA, Prosiding Seminar Nasional Matematika, 3, 591-598. Retrieved from https://journal.unnes. ac.id/sju/index.php/prisma/article/view/37636.

Tyas, A. A. W., \& Wutsqa, D. U. (2015). Analisis kesulitan siswa SMA dalam pemecahan masalah matematika kelas XII IPA di kota Yogyakarta. Jurnal Riset Pendidikan Matematika, 2(1), 28-39. Retrieved from https://journal. uny.ac.id/index.php/jrpm/article/view/7148.

Usman, M. H. \& Hussaini, M. M. (2017). Analysis of students' error in learning of trigonometry among senior secondary school students in Zaria Metropolis, Nigeria. IOSR Journal of Mathematics, 12, 01-04. http:/ / www. iosrjournals.org/iosr-jm/papers/Vol13-issue2/Version-4/A1302040104 .pdf.

Yaman, B. B. (2019). A multiple case study: what happens in peer tutoring of calculus studies? International Journal of Education in Mathematics, 7(1), 5372. https://doi.org/10.18404/ijemst.328336.

Yuwono, M. R. (2016). Analisis kesulitan mahasiswa dalam menyelesaikan soal geometri berdasarkan Taksonomi Bloom dan alternatif pemecahannya. Beta Jurnal Tadris Matematika, 9(2), 111. https://doi.org/10.20414/ betajtm.v9i2.7. 